\title{
Mentally Disabled Citizenship Applicants and the Meaningful Oath Requirement for Naturalization
}

\author{
Joren Lyons $\dagger$
}

In 1994 Congress removed a major barrier to the successful naturalization of legal permanent residents with disabilities, by exempting such applicants from the requirements of English fluency and knowledge of United States history and civics. But applicants with severe mental disabilities are still barred from citizenship by the Immigration and Naturalization Service's interpretation of the oath of allegiance that the law requires for most naturalized citizens. According to the INS, all applicants must be able to affirmatively demonstrate their belief in the principles of the Constitution and their intent to renounce all prior allegiance to any other country. This Comment argues that the agency's focus is misplaced: The history of the requirements which Congress has set for naturalization reveals that its primary concern has been assuring that citizenship applicants pose no threat to national security. This mandate takes the form of inquiring into an individual's attitude toward the fundamental principles underlying the nation's system of government. Although all applicants must undergo such scrutiny, they need not take positive action to demonstrate their allegiance to constitutional principles. Rather, they may satisfy the standard by refraining from conduct which evidences contrary beliefs. Nonetheless, the INS continues to require disabled applicants to affirmatively demonstrate their intent to comply with the provisions of the oath.

Copyright $\odot 1999$ Joren Lyons and the California Law Review, Inc.

$\dagger$ J.D., School of Law, University of California, Berkeley (Boalt Hall), 1999; B.A., University of California, Berkeley, 1994. Many thanks to Professor Stephen Rosenbaum for his invaluable support throughout the writing process, to Professor Rachel Moran for her suggestions on structuring the analysis, and to Professor Marina Hsieh for her encouragement of student writing. On the California Law Review staff, I thank Ping Hin Yu, and especially Kim Sayers-Fay for her many days of labor; her suggestions greatly improved the piece. I dedicate this Comment to my mother, Thetis Cusimano, who has devoted her career to ensuring that special education students can reach their full potential. 
However, the INS is required by the Rehabilitation Act of 1973 to make reasonable accommodations which facilitate participation in the agency's programs by individuals with disabilities, so long as the modifications do not alter the fundamental nature of the program. Given that the fundamental role of the naturalization application process is screening out those who pose a potential threat to the well-being of the nation, the same function could be served by other means. For example, the Immigration and Nationality Act already authorizes the INS to accept testimony and other evidence of an applicant's admissibility to citizenship, such as affidavits that an applicant's conduct is consistent with a belief in constitutional principles. This Comment concludes that the protective screening function of the naturalization process would not be impaired if the INS permitted applicants with severe mental disabilities to naturalize, and that the agency has adequate alternative means at its disposal to ensure that applicants pose no threat to national security.

I hereby declare, on oath, that I absolutely and entirely renounce and abjure all allegiance and fidelity to any foreign prince, potentate, state, or sovereignty, of whom or which I have heretofore been a subject or citizen; that I will support and defend the Constitution and laws of the United States of America against all enemies, foreign and domestic; that I will bear true faith and allegiance to the same; that I will bear arms on behalf of the United States when required by the law; that I will perform noncombatant service in the Armed Forces of the United States when required by the law; that I will perform work of national importance under civilian direction when required by the law; and that I take this obligation freely, without any mental reservation or purpose of evasion; so help me God.

-Oath of allegiance to the United States to be taken upon naturalization. ${ }^{1}$

\section{INTRODUCTION}

Until recently the few practical distinctions between permanent residency and citizenship rarely figured prominently in most immigrants' daily lives. With only voting and eligibility for certain government jobs at stake, ${ }^{2}$ many immigrant families felt no pressing need to seek naturalization. The passage of federal welfare reform legislation in 1996, however, changed

1. 8 C.F.R. $\S 337.1$ (a) (1998) (setting forth the text for the oath of allegiance, as specified by Immigration and Nationality Act $\$ 337$ (a) [hereinafter INA], 8 U.S.C.A. § 1448(a) (West 1999)).

2. See Cabell v. Chavez-Salido, 454 U.S. 432 (1982) (finding citizens-only hiring policy for probation officers permissible); Ambach v. Norwick, 441 U.S. 68 (1979) (same for teachers); Foley v. Connelie, 435 U.S. 291 (1978) (same for police officers). 
this situation dramatically. The Personal Responsibility and Work Opportunity Reconciliation Act restricted permanent residents' eligibility for public benefits, ${ }^{4}$ resulting in widespread anxiety, numerous cases of hardship, and a predictable massive move toward naturalization. ${ }^{5}$ This process has been traumatic for many, especially immigrants with severe mental disabilities ${ }^{6}$ and their families. ${ }^{7}$

Although most naturalization applicants complete the process without special accommodations, there are significant numbers of applicants who do require some degree of accommodation, such as those with mental disabilities. ${ }^{8}$ Each of these permanent residents is entitled to apply for naturalization. But for some, as a result of the Immigration and Naturalization Service's interpretation of the requirements which Congress has set for citizenship, their efforts are doomed from the outset.

In order to naturalize, a typical applicant must first satisfy five basic criteria: (1) five years of legal permanent residency; (2) good moral character; (3) competency in written and spoken English; (4) knowledge of United States history and government; and (5) attachment to the principles of the Constitution and favorable disposition toward the well-being of the

3. Personal Responsibility and Work Opportunity Reconciliation Act of 1996, Pub. L. No. 104 193, 110 Stat. 2105.

4. See id. \$ 402(a)(1) (codified as amended at 8 U.S.C.A. \$ 1612 (West 1999)).

5. See Mirta Ojito, A Record Backlog to Get Citizenship Stymies 2 Million, N.Y. Times, Apr. 20, 1998, at A1. Between 1995 and 1996, the number of people naturalized more than doubled, rising from 488,088 to $1,044,689$. See INS, 1996 Statistical YearbooK OF THE IMMIGRATION AND Naturalization SERvice 147 (1997). In this decade alone, from 1990 to 1996, 3,851,954 individuals were naturalized. See id. at 146.

6. For purposes of this Comment, "severe mental disability" and "severe inental impairment" refer both to profound retardation and to mental disabilities acquired later in life that are incapacitating to a similar degree. See George S. Baroff, Mental Retardation 56 (2d ed. 1986) (describing profoundly retarded adults as those with an IQ of zero to nineteen, with a mental age of zero to four years, and with very limited capacities for communication and interaction with others).

7. See Celia W. Dugger, U.S. Says Mental Impairment Might Be a Bar to Citizenship, N.Y. Times, Mar. 19, 1997, at A1.

8. Although the exact number of inentally disabled immigrants is unknown, with over 500,000 people admitted to the United States each year, there are presumably a substantial number of incoming families with at least one mentally impaired member. See BAROFF, supra note 6, at 14, 19 (reporting that the generally accepted rate of mental retardation in the population at large is one to three percent, with about four percent of this group classified as severely or profoundly impaired); Louis Freedberg \& Ramon G. McLeod, The Other Side of the Law; Despite All U.S. Efforts to Curb It, Immigration Is Rising, S.F. ChroN., Oct. 13, 1998, at A1 (reporting on annual immigration rates). In addition to these new arrivals, a much larger number of older permanent residents lose mental capacity as a result of Alzheimer's disease or strokes each year. This type of cognitive impairment, in which mental capacity is lost due to age-related illness, is far more prevalent than the developmental disabilities mentioned above. See Douglas Galasko \& Leon J. Thal, Alzheimer's Disease, in CoGNITIve Disorders 229, 230 (Leon J. Thal et al. eds., 1992) (reporting that four to five percent of adults over age sixty-five have severe dementia, with about sixty percent of this group suffering from Alzheimer's disease); $G$. Webster Ross \& Jeffrey L. Cummings, Vascular Dementias, in id. at 271, 272 (noting that stroke is the second most frequent cause of severe dementia in elderly patients). 
United States. ${ }^{9}$ To demonstrate their adherence to this last requirement, applicants nust then take an oath to support and defend the Constitution and laws of the United States, and to renounce all allegiance to any other nation. ${ }^{10}$

Until this decade, applicants with disabilities that substantially affected their ability to learn English or to memorize basic civics and history nuaterial had little hope of successfully completing the naturalization process. But in 1994, in recognition of the need to accommodate disabled immigrants and facilitate their transition to citizenship, Congrcss directcd the INS to waive these two naturalization requirements when they impose an unreasonable burden. ${ }^{11}$

Although Congress's action has opened the door to naturalization for nrany previously excluded residents, a significant pool of applicants are still unable to become citizens. For citizenship applicants with the most severe nental disabilities, it is no longer the mipossible task of acquiring new language skills or being able to recite U.S. history on command that bars them from becoming citizens. Rather, it is now the insurmountable barrier of establishing that one's "attitude toward the Constitution and laws of the United States renders him or her capable of fulfilling the obligations" of the oath of allegiance. ${ }^{12}$

The experience of citizenship applicants such as Andrew Lau, ${ }^{13}$ who recently found himself in the midst of this exact dilemma, illustrates the problein. Although he ineets the requirements for length of residency and good moral character, and qualifies for a waiver of the English and U.S. history/civics tests, Mr. Lau was rejected because he has a mental age of three to four. ${ }^{14}$ The specific reason for barring him from citizenship, the INS told him, is that he failed to respond appropriately to questions such as "Do you believe in the Constitution?" and "Do you want to give up your Chinese citizenship?"15 Finally, the INS informcd him that "you were unable to deinonstrate that you understood you were becoming a United States citizen, that you were forswearing allegiance to your country of

\footnotetext{
9. See INA $\S \S 312,316,8$ U.S.C.A. $\S \S 1423,1427$ (West 1999).

10. See id. § 337(a), 8 U.S.C.A. \& 1448(a).

11. See Immigration and Nationality Technical Corrections Act of 1994, Pub. L. No. 103-416, § 108(a), 108 Stat. 4305, 4309-10 (codified at INA § 312(b)(1), 8 U.S.C.A. § 1423(b)(1) (West 1999)). In 1996, when announcing the rules governing the waiver program, the INS estimated that 300,000 permanent residents might apply for these disability waivers. See Exceptions to the Educational Requirements for Naturalization for Certain Applicants, 61 Fed. Reg. 44,227, 44,229 (1996).

12. 8 C.F.R. $\$ 337.1$ (c) (1998).

13. This name is a pseudonym, though the facts of the case are otherwise unaltered.

14. See Letter from Donald A. Radcliffe, District Director, Immigration and Naturalization Service, to Andrew Lau (Nov. 6, 1998) (on file with author) (confirming rejection of naturalization application on grounds of failure to meet the requirement of attachment to the principles of the Constitution and mability to understand the provisions of the oath of allegiance) [hereinafter Radcliffe Letter].

15. Id.
} 
nationality, and that you were personally and voluntarily agreeing to a change in your status to that of a United States citizen. There is no waiver for this requirement." ${ }^{\text {16 }}$

This case is not an isolated incident. Because Congress did not explicitly waive the oath requirement for citizenship, the Immigration and Naturalization Service consistently denies citizenship to those applicants who, in the agency's view, lack the capacity "to understand the nature of the oath" to support and defend the Constitution. ${ }^{17}$ Thus, under the current regulatory schene, a severely mentally disabled individual may legally enter the country and reside here on a permanent basis, but will never be eligible for citizenship. Furthermore, those residents who, in the course of their lives in this country, beconie severely mentally disabled due to accidents or age-related deinentia find theniselves likewise permanently barred fronı citizenship by the INS's interpretation of the oath and its inplied conponent of attachment to the Constitution. Thus, the INS's actions in implementing Congress's 1994 accommodation directive are hampering, rather than increasing, access to citizenship for the nuost vulnerable part of the inentally disabled community-those with severely impaired cognitive abilities.

This Comment challenges the INS's construction of the oath as a necessary component of the naturalization process, arguing that where an applicant can satisfy or show exenuption from each of the five basic substantive criteria for citizenship, the oath is a procedural matter that should not be used as a bar to citizenship. Part I sets the stage for this discussion by briefly examining the trend in U.S. immigration policy toward acceptance of mentally disabled immigrants. Part II then proceeds to investigate the development of the current body of naturalization requirements, noting Congress's recurring focus on excluding citizenship applicants who umght pose a threat to the United States's security. After reviewing Congress's establishment of waivers for the various citizenship criteria and their availability to severely disabled applicants, I find that the baseline requirements for citizenship are (1) good moral character; and (2) attachment to the primciples of the Constitution as expressed in the oath of allegiance. An examination of the two criteria reveals that an applicant nuay satisfy both by passively refraining from actions which might violate these standards. Taking positive action to demonstrate adherence is not required.

16. Id.

17. INS Office of Naturalization Operations, Section 312 Disability Naturalization Adjudications: Supplemental Policy Guidance for Field Offices, Part II, at 1 (Mar. 16, 1998), reprinted in 75 INTERPRETER Releases 557, 557 (1998) [hereinafter Supplemental Policy Guidance II]. The exact number of rejected applicants is unknown, because the INS has not released any statistics on the number of cases that it has denied. See Interview with Stephen Rosenbaum, Staff Attomey, Protection \& Advocacy, Inc., in Berkeley, Cal. (Oct. 11, 1998). 
Since it is thus possible for applicants with severe mental disabilities to meet all of the prerequisites for citizenship, only the INS's construction of the oath requirement remains as a barrier to successful naturalization. I therefore turn to an exploration of the specific situations in which Congress and the courts have seen fit to waive or modify the oath itself, concluding that a similar rationale supports waiving the oath for applicants with severe mental disabilities. Part III bolsters this finding by reviewing Congress's 1973 establishment of a reasonable accommodation policy to facilitate the participation of disabled individuals in federal government programs and in society as a whole. Part III also reviews Congress's specific action on behalf of disabled citizenship applicants in 1994. I note that despite these mandates, the INS has steadfastly maintained that applicants whose mental impairments preclude them from taking a meaningful oath of allegiance are barred from citizenship, thereby nullifying in large part Congress's creation of the disability waiver program.

In response to the INS's stance that it is legally obligated to enforce the oath requirement in this manner, Part IV then applies existing law to support waiving the oath for the most severely disabled applicants. I argue that Congress's 1994 disability waiver authorization, working together with the reasonable accommodation requirements of the Rehabilitation Act of 1973 and the existing powers delegated to the INS by the Immigration and Nationality Act, authorizes the INS to waive the meaningful oath requirement if necessary. Mindful of the fact that Congress has charged the INS with maintaining and enforcing a meaningful set of standards for adimission to citizenship, I explore alternative means that the agency could employ to satisfy Congress's concerns regarding naturalizing potential citizens who might endanger the Umited States. I conclude that the INS's mission would not be compromised by admitting applicants with severe mental disabilities to citizenship.

\section{I}

The Historical Treatment of Immigrants With Mental Disabilities: Exclusion Gradually Gives Way to TOLERANCE

The INS's failure to accommodate mentally disabled citizenship applicants does not spring from a vacuum. Rather, it reflects a history of discrimination against disabled immigrants that has unfortunately characterized American immigration law since its inception. The Act of August 3,1882, the first federal immigration law of general applicability, ${ }^{18}$

18. See Act of Aug. 3, 1882, ch. 376, $\S 1-2,22$ Stat. 214, 214 (requiring examination of "each and every" non-citizen passenger arriving by ship). Congress's two previous forays into immigration law dealt with the exclusion of Chinese and Japanese immigrants. See Act of May 6, 1882, ch. 126, 22 Stat. 58; Act of Mar. 3, 1875, ch. 141, 18 Stat. 477. 
specifically barred the entry of any "lunatic, idiot, or any person unable to take care of himself or herself without becoming a public charge." lar grounds of exclusion featured prominently in every major immigration statute for decades thereafter, ${ }^{20}$ reflecting American society's embrace of eugenic ideals and its growing obsession with Darwiman concepts of fitness. ${ }^{21}$

The most prominent manifestations of this trend, such as phrenology ${ }^{22}$ and craniometry, ${ }^{23}$ and later the ready acceptance of intelligence testing, all reflected the then-prevalent idea that everything about the human body and mind could be measured and ranked for comparison. ${ }^{24}$ Intelligence was no exception. Perhaps unsurprisingly, those conducting intelligence testing frequently confirmed their own beliefs about the intellectual inferiority of new arrivals. ${ }^{25}$ These notions of the inherently low mental fitness of the majority of new immigrants permeated governmental attitudes as well. For example, Secretary of Labor James Davis devoted an entire book to the topic, endorsing a plan of selective admission that would grant entry only to those "who are fit to become incorporated in our social and civie structure. In this way we can do much toward keeping the blood of the nation unpolluted by inferior strain."26

To further guard against the prospect of admitting "unfit" individuals, the Immigration Act of $1917^{27}$ introduced a literacy requirement. ${ }^{28}$ The Act also greatly expanded the list of excludable aliens. The focus on mental

19. Act of Aug. 3,1882 $\S 2,22$ Stat. at 214. Under the Act, immigrants arriving by ship paid a fifty-cent tax, part of which funded an examination of every arrival for excludability. See id. $\S 1,22$ Stat. at 214.

20. See, e.g., Act of Feb. 20, 1907, Pub. L. No. 59-96, § 2, 34 Stat. 898, 898 (barring "idiots, iubeciles, feeble-minded persons," and anyone whose physical or mental disability would affect his or her capacity to earn a living); Act of Mar. 3, 1903, Pub. L. No. 57-162, § 2, 32 Stat. 1213, 1214 (barring "[a]ll idiots, insane persons, epileptics, and persons who have been insane within five years previous; persons who have had two or more attacks of insamity at any time previously; ... [and] persons likely to become a public charge"); Act of Mar. 3, 1891, ch. 551, § 1, 26 Stat. 1084, 1084 (excluding "idiots, insane persons ... or persons likely to becoine a public charge").

21. See generally STEPhen JAY Gould, The Mismeasure of MAN (1981) (discussing nineteenth and early twentieth century attempts to quantify human intelligence and its heritability).

22. Phrenology was a nineteenth-century pseudoscience that held that the shape of the skull revealed an individual's mental capacity and innate character traits. See WEBSTER's THIRD NEW INT'L DictionaRY 1704 (1993).

23. Craniometry was a field of study that focused on measurement of the skull, especially racial differences in skull shape and size. See id. at 530.

24. See generally Gould, supra note 21 (chronicling the irresistible urge to measure every aspect of the brain's anatomy and function).

25. See id. at 164-68.

26. James J. DAVIS, Selective ImMigration 18 (1925). Davis's choice of rhetoric reflects a dual prejudice: Conventional wisdom in the early part of this century held that eastern and southern Europeans (and all non-whites) were both socially and biologically undesirable, and would either never assimilate, or $\mathrm{m}$ doing so would drag the nation down to their degraded level of existence. See GovLD, supra note 21, at 164-68.

27. Pub. L. No. 64-301, 39 Stat. 874 (1917).

28. See id. § 3. An immigrant could select any language to demonstrate literacy. See id. 
disabilities was clear: Among those barred from entry were "idiots, imbeciles, feeble-minded persons, epileptics, insane persons;" those who had experienced "one or more attacks of insanity at any time;" persons of "constitutional psychopathic inferiority;" anyone with a physical or mental "defect" that might affect her ability to earn a living; and persons likely to become public charges for any reason. ${ }^{29}$

The 1917 Act, however, also established a limited waiver system to anieliorate its potential impact on immigrant families. The Act permitted the immigration of otherwise excludable illiterate individuals who were the parents, grandparents, wives, or single daughters of an admissible male immigrant. ${ }^{30}$ In the aftermath of World War II, Congress again softened immigration requirements in order to keep families intact, this time approving the admission of mentally and physically disabled spouses and children of veterans. ${ }^{31}$ Thus, even during the restrictionist period, the ban on immigrants with mental disabilities was by no means absolute, at least where close family ties played a role.

The 1952 Immigration and Nationality $\mathrm{Act}^{32}$ (INA), which continues to be the basis for modern immigration law, incorporated this sanie general statutory framework. Like its predecessors, it contained a broad ban on the immigration of illiterates, ${ }^{33}$ the "feeble-minded,"34 and those likely to become public charges, ${ }^{35}$ while preserving (and gradually expanding) various discretionary waivers for family members. ${ }^{36}$ This system of hurdles for immigrants with mental disabilities persisted until 1990, when Congress replaced it with a more narrowly focused criterion: The INA now prohibits only the immigration of those with mental disorders resulting in behavior that may cause harm to themselves or others. ${ }^{37}$ This bar itself may be waived for relatives of U.S. citizens or permanent residents who are otherwise eligible to immigrate. ${ }^{38}$

29. Id. The Act also strengthened existing bans on prostitutes, pimps, anarchists, contract laborers, and virtually all immigrants from Asia. See id.

30. See id.

31. See Act of Dec. 28, 1945, Pub. L. No. 79-271, § 1, 59 Stat. 659, 659.

32. Pub. L. No. $82-414,66$ Stat. 163 (1952).

33. See id. \$212(a)(25).

34. Id. § 212(a)(1).

35. See id. \$212(a)(15).

36. See, e.g., Immigration and Nationality Act Amendments of 1965 , Pub. L. No. 89-236, § 15(c), 79 Stat. 911,919 (1965) (creating a waiver for the admission of mentally disabled family members); INA $\$ 212$ (b) (waiving the illiteracy bar for family members).

37. See Immigration Act of 1990, Pub. L. No. 101-649, § 601(a), 104 Stat. 4978, 5067 (codified at INA $\S 212(\mathrm{a})(1)(\mathrm{A})(\mathrm{iii}), 8$ U.S.C.A. $\S 1182(\mathrm{a})(1)(\mathrm{A})(\mathrm{iii})$ (West 1999)); see also 8 C.F.R. $\S$ 212.7(b)(4)(ii) (1998) (requiring submission of a medical report to the U.S. Public Health Service, and the Service's approval).

38. See INA § 212(g)(3), 8 U.S.C.A. § 1182(g)(3) West 1999); 8 C.F.R. § 212.7(b) (1998). The broad bar on those likely to become public charges also persists, and could potentially affect immigrants with severe mental disabilities, but it too may be waived upon receipt of an affidavit of support from a family member. See INA § 212(a)(4), 8 U.S.C.A. § 1182(a)(4) (West 1999). However, 
As a result of these increasingly inclusionary policies, a substantial number of families with mentally disabled members have immigrated ${ }^{39}$ This population of mentally impaired permanent residents, together with the existence of a substantial number of elderly immigrants who develop Alzheimer's or stroke-induced dementia years after their arrival, ${ }^{40}$ has prompted Congress to re-examine and modify its requirements for naturalization. Below, I trace the evolution of the citizenship requirements that Congress has seen fit to establish, including its recent efforts to accommodate naturalization applicants with mental disabilities.

III

\section{NATURALIZATION RequiREMENTS aNd AVAILAble WaIVERS}

\section{A. Evolution of the Naturalization Requirements}

The first laws governing naturalization appeared eighty-five years before Congress imposed any restrictions on entry to the United States. ${ }^{41}$ Soon after its imception, naturalization law began to reflect Congress's focus on the applicant's degree of attachment to the United States. Starting in 1795 , prospective citizens had to appear im court to renounce their loyalty to any foreign government, swear their support for the Constitution of the United States, and satisfy the court that their behavior refiected good moral character, attachment to the primciples of the Constitution, and a favorable disposition toward the good order and happiness of the United States..$^{42}$ In addition, applicants had to have resided in the United States for at least five years and have filed a declaration of intent to renounce all former allegiances three years prior to applying for citizenship..$^{43}$ After a brief bout of anti-immigrant hysteria lengthened the necessary residency period

the State Department has directed its officers to give special scrutiny to affidavits of support filed on behalf of disabled immigrants. See Department of State, I-864 Affidavit of Support: Update No. 14 Commitment to Provide Assistance at II 6 (June 8, 1998), reprinted in 75 INTERPRETER RelEASEs 879, 880 (1998).

39. 'See supra note 8.

40. See id.

41. See Act of Mar. 26, 1790, ch. 3, § 1, 1 Stat. 103, 103 (requiring only two years of residency, good character, and taking of an oath to support the Constitution, but limiting citizenship ehgibility to "free white person[s]").

42. See Act of Jan. 29, 1795, ch. 20, §§ 1-2, 1 Stat. 414, 414-15.

43. See id. $\S 1$. The declaration of intent is no longer mandatory today. See INA $\S 334(f), 8$ U.S.C.A. § 1445(f) (West 1999). 
considerably, ${ }^{44}$ the original basic requirements were reenacted in $1802 .^{45}$ All survive to the present day. ${ }^{46}$

Since the passage of the Naturalization Act of 1906, Congress has also required prospective citizens to demonstrate the ability to speak English. ${ }^{47}$ Some courts zealously exercised their power in the naturalization screening process, going so far as to require applicants to demonstrate their knowledge of written English as well. In an illustrative 1927 case, In re $\mathrm{Katz}^{48}$ a judge took an applicant to task for his illiteracy in English:

[I]t is well within the court's discretion to require among other things that an applicant for citizenship shall display some ability to read the English language to the end that the alien familiarize himself with our Constitution, our laws and our customs and thus fulfill [the requirements of attachment to the Constitution and favorable disposition toward the United States] .... Not only is it at least doubtful whether an alien can be said to be sufficiently attached to the principles of a written document which he cannot read, and of which, therefore, his understanding must necessarily be limited and uncertain, but it is also obvious that an alien who claims to be attached to the principles of that great docuinent, and yet has been unwilling to devote the time and effort necessary to enable him to read it, is not sufficiently interested in, nor attached to, its principles to entitle him to the privilege of American citizenship. ${ }^{49}$

The Katz court was prescient in two regards. First, the Nationality Act of $1940^{50}$ codified the court's emphasis on knowledge of the Constitution. Although the Act did not specify English literacy, it required an inquiry into an applicant's "understanding of and attachment to the fundamental

44. The Act of June 18, 1798, ch. 54, 1 Stat. 566, increased the residency period to fourteen years and imposed other restrictions. For a discussion of the xenophobia that gave rise to this legislation, see Select Comm'N on Immigration \& Refugee Policy, U.S. ImMigration Policy and the National INTERest, reprinted in ThOMAs AleXANDER AleINIKOFF ET al., IMMIGRation aND Citizenship 152, 154 (4th ed. 1998).

45. See Act of Apr. 14, 1802, ch. 28, § 1, 2 Stat. 153, 153.

46. The original basic requirements all survive today with the notable exception of the racial restrictions, which Congress slowly chipped away at and finally abolished in 1952. See Immigration and Nationality Act, Pub. L. No. 82-414, § 311, 66 Stat. 163, 239 (1952). For further reading on the effects of these bars, see Enid Trucios-Haynes, The Legacy of Racially Restrictive Immigration Laws and Policies and the Construction of the American National Identity, 76 OR. L. REv. 369, 400-08 (1997). Aside from its limitation to "free white persons," the same basic prerequisites that the Act of 1802 restored may now be found in INA $\$ 316,8$ U.S.C.A. $\$ 1427$ (West 1999) (requiring five years of residency, good moral character, attachment to the principles of the Constitution, and favorable disposition toward the United States), and INA § 337, 8 U.S.C.A. $\$ 1448$ (West 1999) (requiring that each applicant take an oath of renunciation and allegiance).

47. See Act of June 29, 1906, Pub. L. No. 59-338, \& 8, 34 Stat. 596, 599.

48. 21 F.2d 867 (E.D. Mich. 1927).

49. Id. at 867-68.

50. Pub. L. No. 76-853, 54 Stat. 1137. 
principles of the Constitution."51 Ten years later, the court's insistence on English literacy also became the law of the land: The Subversive Activities Control Act of $1950^{52}$ officially expanded the extant oral English requirement to encompass literacy as well..$^{53}$ Commenting on this change, the bill's author, Senator Patrick McCarran, opined that those who could not read English could not fully develop an understanding of American principles of democratic government, nor completely comprehend the conduct of the nation's affairs. ${ }^{54}$ McCarran posited that this isolation left individuals vulnerable to manipulation by foreign-language Communist propaganda and biased news coverage. ${ }^{55}$

Soon afterward Congress embarked on a major overhaul of immigration law, resultimg in the passage of the Immigration and Nationality Act ${ }^{56}$ (INA) in 1952. The INA retained the new English literacy requirement, and also expanded the 1940 Nationality Act's requirement of knowledge of the Constitution to encompass "a knowledge and understanding of the fundamentals of the history, and of the principles and forin of government, of the United States." 58

Beyond requiring would-be citizens to actively acquire a working knowledge of the principles of American government, the INA also sought to screen out those who disagreed with these principles, explicitly rendermg members of "subversive" groups, such as the Communist Party, ineligible for citizenship..$^{59}$ This bar still exists today, and represents the culmination of a series of provisions excluding those who hold opinions deemed adverse to the United States's system of government. ${ }^{60}$ Further evincing its preoccupation with loyalty to the nation, Congress has also banned the naturalization of those who have deserted from the military or who have avoided military service by relying on their foreign citizenship. ${ }^{61}$ Like the good moral character requirenient and the requirement of attachment to the Constitution and favorable disposition toward the well-being of the United States, these bars to naturalization seek to exclude those who

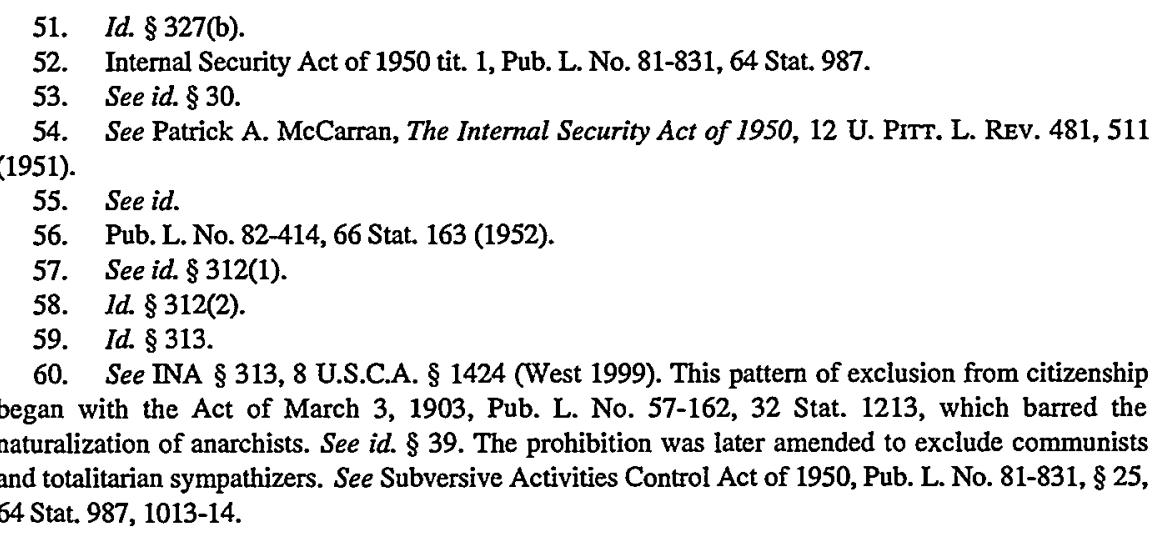

61. See INA §§ 314, 315, 8 U.S.C.A. §§ 1425, 1426 (West 1999). 
willfully disregard the laws and norms of the nation or who threaten its existence. Conversely, when loyalty to the United States is not at issue, Congress has relaxed or waived the other naturalization requirements where necessary to maintain access to citizenship.

\section{B. The Proliferation of Waivers}

Just as loyalty has played a major role in shaping naturalization requirements, it also animates the exceptions to those requirements. Displaying little tolerance of disloyalty or disrespect for the law, Congress has consistently maintained unaltered the requirements of attachment to the Constitution and good moral character. At the saine time, however, it has provided for waivers to the other three requirements for naturalization: the English language requirement, knowledge of American history and government, and five years of permanent residency. Below, I discuss these requirements in turn.

From the very inception of the English language requirement, Congress recogmized that a lack of fluency in English was not necessarily a bar to being a good citizen: Applicants "physically unable to comply" with the 1906 statute's standard of English fluency due to deafness or blindness were exempted in the original legislation. ${ }^{62}$ This exemption, which Congress eventually expanded to include the literacy requirement as well, persisted for almost ninety years, and is now incorporated into the general disability waiver which the legislature created in $1994 .{ }^{63}$

When it adopted the English literacy requirement in 1950, Congress again took pains to mitigate its effects, particularly its impact on older, long-term permanent residents. To achieve this goal, the legislature incorporated a grandfather-clause waiver of the English requirement for those who, on the date of its enactment, were over age fifty with twenty years of permanent residency.$^{64}$ More than a quarter-century later, Congress revived the English waiver program; the new waiver set the same age and residency criteria - but this time without imposing any cutoff date for eligibility. ${ }^{65}$ In keeping with its desire to reward loyalty, Congress was spurred to action on this issue by a particularly compelling private bill to benefit Eugenia Cortes, an elderly Cuban-American widow who had seven U.S. citizen children (including several veterans) and an impeccable record of

62. Act of June 29, 1906, Pub. L. No. 59-338, § 8, 34 Stat. 596, 599.

63. See INA § 312,8 U.S.C.A. $\S 1423$ (West 1999).

64. See Subversive Activities Control Act of 1950 \& 30. This waiver was carried over into the Immigration and Nationality Act of 1952. See Pub. L. No. 82-414, § 312(1), 66 Stat. 163, 239.

65. See Act of Nov. 2, 1978, Pub. L. No. 95-579, § 3, 92 Stat. 2474, 2474 (codified at INA \& 312(b)(2)(A), 8 U.S.C.A. $\S 1423(b)(2)(A)$ (West 1999)). 
community service and church attendance.$^{66}$ In 1990 , the English waiver program that Ms. Cortes inspired also became available to those over age fifty-five with fifteen years of permanent residency ${ }^{67}$ For naturalization applicants who can meet these criteria, the ability to speak and read English is no longer an essential prerequisite for citizenship.

Congress next turned its attention to the requirement for knowledge of U.S. history and civics, providing for its reduction or complete waiver in the Immigration and Nationality Technical Corrections Act of 1994 (INTCA). ${ }^{68}$ INTCA reduced the burden on elderly citizenship applicants by creating a special program for those over sixty-five with niore than twenty years of permanent residency. ${ }^{69}$ As a result, qualified seniors are now asked questions from a freely available set of twenty-five eleznentary history and civics questions, all in their native language. ${ }^{70}$ In addition, applicants of any age with qualifying disabilities ${ }^{71}$ inay apply for complete waivers of both the English language and U.S. history/civics requirenients. ${ }^{72} \mathrm{By}$ accommodating disabled applicants in removing these two requirements, Congress has left only permanent residency, ${ }^{73}$ good noral character,${ }^{74}$ and

66. See id. \$ 1; Sung-Ae Choi, The Elderly, Limited Enghsh Proficient Citizen Within the Asian American Community 16-22 (Dec. 14, 1998) (unpublished manuscript on file with author) (discussing the evolution of the private bill into a public law).

67. See Immigration Act of 1990, Pub. L. No. 101-649, § 403, 104 Stat. 4978, 5039 (codified at INA § 312(b)(2), 8 U.S.C.A. § 1423(b)(2) (West 1999)).

68. INTCA, Pub. L. No. 103-416, § 108, 108 Stat. 4305, 4309-10 (1994) (codified at INA § 312(b), 8 U.S.C.A. $\$ 1423$ (b) (West 1999)). Normally, applicants are required to demonstrate their knowledge of U.S. history and government, as well as written Enghish, in a written test administered no more than a year before an applicant files for naturalization. See 8 C.F.R. $\$ 312.3$ (1998). If an applicant elects not to take the written test, she will be required to answer oral questions on history and government during the interview, and must also demonstrate reading and writing ability in English. See id. $\S \S 312.1(\mathrm{c}), 312.2(\mathrm{c})$.

69. See INA § 312(b)(3), 8 U.S.C.A. § 1423(b)(3) (West 1999).

70. See Interview with John Young, Director, San Francisco Immigrant Rights Comm'n, in San Francisco, Cal. (Feb. 11, 1999) (copy of these questions on file with author).

71. The Congressional Report accompanying the legislation defined the necessary level of disability as a permanent condition "resulting in intellectual functionng so impaired as to render the individual unable to participate in the normal testing procedures for naturalization." H.R. REP. No. 103-387, at 5-6 (1993), reprinted in 1994 U.S.C.C.A.N. 3516, 3518.

72. See INTCA $\S 108$ (a), 8 U.S.C.A. $\S 1423(b)(1)$ (West 1999). This waiver is explored in more detail in Part III.A infra. It is also worth noting that the Immigration Reform and Control Act of 1986, which allowed undocumented residents to adjust their status to that of legal permanent residents, but required a knowledge of English and U.S. history/civics, foreshadowed INTCA by including a waiver for those over age sixty-five. See Pub. L. No. 99-603, $\$ 201$ (a), 100 Stat. 3359, 3396 (codified at INA $\S$ 245A(b)(1)(D)(ii), 8 U.S.C.A. $\$ 1255 a(b)(1)(D)(i i)$ (West 1999)). In 1988, Congress made developmentally disabled individuals eligible for the waiver as well. See Immigration Technical Corrections Act of 1988, Pub. L. No. 100-525, § 2(h)(1)(B), 102 Stat. 2609, 2611 (codified at INA § 245A(b)(1)(D)(ii), 8 U.S.C.A. $\S 1255 a(b)(1)(D)(i i)$ (West 1999)).

73. See 8 C.F.R. $\$ 316.5$ (1998).

74. See id. §316.10. 
attachment to the principles of the Constitution ${ }^{75}$ as essential prerequisites for citizenship.

The residency requirement, normally five years, serves to ensure that an individual will have sufficient time to integrate and find a place in the local and national community, theoretically becoming attached to the United States during this process. ${ }^{76}$ But when strong signs of attachment to the United States are otherwise evident, this requirement is routinely reduced. For example, spouses of U.S. citizens need only wait three years before naturalizing, due to their presumed stronger ties to this nation (or at least to one particular member of the nation). ${ }^{77}$ One court, in commenting on this provision, noted that "a non-citizen spouse who lived in close association with a citizen spouse for three years would more speedily absorb the basic concepts of citizenship than one not so situated."78 Outside the private sphere of family ties, military service on behalf of the United States is also taken to be powerful evidence of loyalty: Immigrants with service in the Armed Forces may also becoine citizens after just three years of permanent residency. ${ }^{79}$ Congress has also mandated that foreign nationals who served with U.S. troops in World War I, World War II, the Korean War, or the Vietnam War be immediately eligible for naturalization upon obtaining permanent residency, in light of their contributions to American society. ${ }^{80}$ Taken in concert, these waivers suggest that the five-year residency requirement functions more as an proxy for attachment to the United States than as an independent hurdle. Where facts other than length of residency evidence strong ties to the Umited States, Congress has readily dispensed with the full five-year requirement.

While it has not deemed the English, U.S. history/civics, and five-year residency criteria essential, Congress has been nore adamant with regard to the requirements of good moral character and attachment to the Constitution. These two criteria implicate notions of adherence to commumity values, laws, and the Umited States's system of government. For applicants with severe mental disabilities, the key question is whether Congress requires positive action on the applicant's part to show adherence to these two criteria, or whether it is sufficient to passively refrain from contrary actions.

Turning first to the good noral character requirement, we find it defined largely in terms of the avoidance of prohibited acts. Only when a

\footnotetext{
75. See id. $\$ 316.11$.

76. See DAVID Weissbrodt, ImMigration LAW AND Procedure 345 (4th ed. 1998).

77. See INA § 319(a), 8 U.S.C.A. § 1430(a) (West 1999).

78. In re Kostas, 169 F. Supp. 77, 78 (D. Del. 1958).

79. See INA § 328(a), 8 U.S.C.A. § 1439(a) (West 1999).

80. See id. $\S 329,8$ U.S.C.A. $\S 1440$ (West 1999). The INA also provides for a posthumous award of citizenship to those who died as a result of their serviee. See id. § 329A, 8 U.S.C.A. § 1440-1 (West 1999).
} 
naturalization examiner has evidence that an applicant has violated the law or flouted a basic moral convention will the applicant be found to lack good moral character; there is no corresponding requirement of positive action (e.g., commumity service work) ${ }^{81}$ INS officers are to "evaluate claims of good moral character on a case-by-case basis," taking into account a host of potential transgressions. ${ }^{82}$ To determine whether the applicant can conduct herself in accordance with "the standards of the average citizen in the community of residence," 83 investigators consider whether the applicant "had an extramarital affair which tended to destroy an existing marriage," "is or was a habitual drunkard," "willfully failed or refused to support dependents," or "earns his or her income principally from illegal gambling activities."

In addition to avoiding the above activities, an applicant must possess a record free of all but the most minor criminal infractions for the five-year period immediately preceding his or her application. ${ }^{85}$ Any aggravated felony conviction permanently bars an applicant from seeking citizenship. ${ }^{86} \mathrm{In}$ essence, although minor past offenses may be forgiven, an individual intending to become a citizen must steer clear of criminal activity and immoral behavior. A failure to do so will be imterpreted as an impermissible lack of regard for American legal institutions and community values.

Generally speaking, however, the good moral character requirement is rarely a factor for severely mentally disabled applicants. ${ }^{87}$ As a group, these applicants have an extremely low incidence of criminal convictions. ${ }^{88} \mathrm{In}$ volvement in gambling, extramarital affairs, and alcohol consuniption is similarly absent. ${ }^{89}$ Thus, the good moral character requirement poses no real barrier to the acquisition of citizenship by applicants with severe mental disabilities. Since these applicants can also satisfy the necessary residency period, and the English and history/civics requirements are waived, there remains only the criterion of attachment to the Constitution

81. See id. § 316(a), 8 U.S.C.A. $\S 1427$ (a) (West 1999); 8 C.F.R. § 316.10 (1998).

82. 8 C.F.R. $\$ 316.10(\mathrm{a})(2)$ (1998).

83. Id.

84. Id. $\S 316.10(\mathrm{~b})$. This scrutiny applies to the required period of residence (either the last three or five years). See id. $\$ 316.10$ (a)(1).

85. See id. $\S 316.10(b)(2)$. The relevant period is three years for those married to United States citizens. See id.

86. See id. § 316.10(b)(1)(ii). This rule applies to convictions entered on or after November 29, 1990. See id.

87. It is only fair to note, however, that a person whose impairment results from a stroke or other disabling event later in life could have violated the dictates of the good moral character requirement before becoming severely disabled. In such a case, the ramifications of the individual's past acts would presumably continue to bar her from citizenship.

88. See Baroff, supra note 6, at 55-56 (describing low level of contacts with the criminal justice system for moderately, severely, and profoundly retarded individuals).

89. See id. 
and favorable disposition toward the well-being of the United States. It is to this final requirement that we now turn our attention.

\section{The Oath as a Demonstration of Attachment to the Constitution}

When one considers that Congress in 1994 relieved mentally disabled applicants of their burden of becoming familiar with "the principles and form of government of the United States," how the requirement of attachment to the principles of the Constitution survives at all for members of this group. Yet according to the INS, it does indeed survive, and is inextricably intertwined with the oath of allegiance. In denying cases on the grounds that an applicant's inability to understand the oath's ineaning renders its value nugatory, the agency has required the applicant to establish that "his or her attitude toward the Constitution and laws of the United States renders him capable of fulfilling the obligations" of the oath.' It thus appears that the agency is equating attachment with willingness and capacity to take the oath, in order to have some tangible way of assessing whether an applicant satisfies this component of the naturalization requirements.

Due to the abstract nature of attachment, demonstrating the requisite affimity for Constitutional principles poses particularly acute difficulties for applicants with severe mental disabilities. But both the courts and the INS itself have approved defmitions of attachment that such applicants can satisfy. One court, in examining an applicant's attachment as a measure of her eligibility to take the oath of allegiance, ruled that citizenship should be withheld "[o]nly if the applicant's beliefs would deny others civil and constitutionally protected rights or if the applicant believes in a change of our form of government through violence." 92 Under the baseline standard advanced by the court in this case, applicants with severe mental disabilities would seem to be admissible without any gross distortion of the screening function of the naturalization process. In the INS's own interpretation of the requirement, the basic purpose of the standard is similarly clear: Attachment and favorable disposition ${ }^{93}$ "contemplate the exclusion from citizenship of applicants who are hostile to the basic form of

90. INA \& 312(a)(2), 8 U.S.C.A. \& 1423(a)(2) (West 1999).

91. Radcliffe Letter, supra note 14 (making reference to 8 C.F.R. $\$ 337.1$ (c) (1998)).

92. In re Battle, 379 F. Supp. 334, 337 (E.D.N.Y. 1974).

93. Recall that the INA requires an applicant to be both attached to the principles of the Constitution and "well disposed to the good order and happiness of the United States." INA § 316(a), 8 U.S.C.A. § 1427(a) (West 1999). Several courts have uoted that this favorable disposition prong of the requirement "doubtless was inserted in order to exclude from citizenship persons who disbelieve in the form of government embodied in our Constitution or are hostile to it." In re Shanin, 278 F. 739, 740 (D. Mass. 1922); see also In re Arbesn, 347 F. Supp. 1014, 1016 (E.D. La. 1972) (citing Shanin for its treatment of favorable disposition). The favorable disposition requirement thus appears largely redundant, and courts in practice have tended to focus on attachment to the principles of the Constitution. 
government of the Umited States, or who disbelieve in the principles of the Constitution." 94 Given the difficulty of peering into the human mind, these standards must necessarily focus on outward conduct as a reflection of an applicant's inner views. ${ }^{95}$ Once again, as with the good moral character requirement, we find that refraining from action (here, action that harms the United States) suffices to meet this baseline standard.

The criteria for behavior are clear: Congress has repeatedly acted to foreclose the naturalization of applicants whose loyalty to the Umited States is questionable. For example, as we have seen, current members of anarchist, totalitarian, or communist organizations, military deserters, and those who have evaded military service by relymg on their foreign citizenship canuot be naturalized.96 The INA further mandates denaturalization for those who join communist or totalitarian groups within five years of obtaining citizenship. ${ }^{97}$ Even native-born citizens may be stripped of their citizenship for engaging in treason. ${ }^{98}$

Establishing a presumption of attachunent in the absence of these and other similar disloyal acts would not subvert Cougress's goal of safeguarding the nation. In fact, such a provision already exists in an analogous situation. INS regulations specifically note that, in the case of an applicant who is legally incompetent for soine portion of the five-year required residency period, "[t]here is a presumption that the applicant's good moral character, attachınent, and favorable disposition" continue through the period of incompetency. ${ }^{99}$ One might then reasonably infer that the attachinent requirement could also be satisfied by an applicant with severe mental disabilities without endangering the sanctity of the naturalization process or somehow jeopardizing the safety of the natiou.

94. 8 C.F.R. $\$ 316.11$ (a) (1998). The same subsection of the regulations includes the seemingly contradictory assertion that "[a]ttachment implies a depth of conviction which would lead to an active support of the Constitution." Id. Both this language and that quoted in the text above strongly track the court's language in Shanin See Shanin, 278 F. at 740 (stating that attachment "implies, I think, a depth of conviction which would lead to active support of the principles in question ...."); see also supra note 93 (discussing and quoting Shanin). The apparent contradiction in the INS's formulation can be resolved by an examination of the facts in Shanin. The case involved a petition filed by a young man who had avoided inilitary service in World War I based on his non-citizen status, then sought citizenship after the war ended. The judge denied his application on grounds of lack of attachment, noting that he had rejected the opportunity to prove his active support of the Constitution through military service. See Shanin, 278 F. at 740-41. Citizenship applicants with severe mental disabilities, on the other hand, are exempt from the type of "active support"-military service-that the court required of Mr. Shanin. See 50 U.S.C. \& 454(a) (1994) (requiring physical and mental examination to determine suitability for induction into the Armed Forces).

95. See Arbesu, 347 F. Supp. at 1017 (citing In re Sittler, 197 F. Supp. 278 (D.C.N.Y. 1961), aff'd, 316 F.2d 312 (2nd Cir. 1963), cert. denied, 376 U.S. 932 (1964)).

96. See INA $\S \S 313-315,8$ U.S.C.A. $\$ \S 1424-1426$ (West 1999).

97. See id. $\$ 340$ (c), 8 U.S.C.A. \$ 1451(c).

98. See id. \$ 349(a)(7), 8 U.S.C.A. \$ 1481(a)(7).

99. 8 C.F.R. $\$ 316.12$ (b)(1) (1998). 
Ironically, although they are perhaps the least likely of all applicants to harbor harmful intentions toward the United States, severely mentally disabled immigrants continue to be denied citizenship for failure to affirmatively demonstrate their attachment to the Constitution, and thus their capacity to take a meaningful oath of allegiance to uphold its principles. Under current INS policy, even disabled applicants who qualify for a waiver of all testing criteria (including a knowledge of the principles and form of government of the United States) nuust denionstrate the capacity to take the oath in sone form. ${ }^{100}$ The agency now requires individual INS examiners to determine whether an applicant can at least understand a "simplified" version of the oath in her native language. ${ }^{101}$ This includes attempting to discern whether a severely mentally disabled applicant "understands that he or she is becoming a United States citizen, is foreswearing allegiance to his or her other country of nationality, and personally and voluntarily agrees to this change of his or her status." 102

In one particularly bizarre example, during an interview in San Francisco with a severely developinentally delayed young wonian, an INS officer repeatedly held out a teddy bear carrying an American flag, apparently using the woman's reaction to gauge her degree of personal identification with the United States. ${ }^{103}$ The officer finally took her refusal to accept the proffered bear as an indication that she did not possess the requisite attachment to the United States. ${ }^{104}$ Other applicants around the country have likewise met with rejection based on an inferred lack of attachment. ${ }^{105}$

In the INS's view, this policy reflects Congress's intent to require some positive demonstration of allegiance even from applicants who

100. See Supplemental Policy Guidance II, supra note 17, at 1-2, 75 INTERPRETER RELEASEs 557 58 (1998).

101. Louis D. Crocetti, INS Associate Commissioner, Section 312 Disability Naturalization Adjudications: Supplemental Policy Guidance for Field Offices 15 (Mar. 12, 1997), reprinted in 74 INTERPRETER ReleAses 941, 948 (1997) [hereinafter Supplemental Policy Guidance $\Pi$ ].

102. Id. Oddly, INS examiners are making these determinations on mental capacity, rather than the medical professionals who are required for the initial disability waiver certification. See 8 C.F.R. $\S$ 312.2(b)(2) (1998); Supplemental Policy Guidance I, supra note 101, at 15, 74 INTERPRETER RELEASES at 948 . INS's own memo reinforces this contradiction, noting that "[0]fficers should always remember that they are responsible for determining the eligibility for naturalization, not for making or rendering a medical determination." Id. at 10,74 INTERPRETER RELEASES at 945 . It would secm that a decision on whether someone has the capacity to comprehend the oath is a "medical determination," on the same order as deciding whether a person's disability significantly impairs her ability to comply with the English and U.S. history/civics requircments.

103. See Second Amended Complaint for Injunctive and Declaratory Relief at II 52, Chow v. Meissner, 1997 WL 285066 (N.D. Cal. May 22, 1997) (No. C-96-2422 SI).

104. See id.

105. See, e.g., Radcliffe Letter, supra note 14; see also Interview with Stephen Rosenbaum, supra note 17. 
satisfy all other naturalization criteria. ${ }^{106}$ In other words, the agency has defined the oath (as a measure of attachment) to be the irreducible minimum for naturalization, despite its obvious and foreseeable effect on severely mentally disabled applicants. Although Congress did not broach the oath issue when it passed INTCA in 1994, the INS has since transmuted simple silence on this poimt imto a clarion call to defend the gates of membership in the body politic. As a result, those who will not and those who cannot express their willingness to uphold the principles of the Constitution find themselves lumped together in the same category of inadmissible citizenship applicants.

\section{Existing Waivers and Modifications for the Oath of Allegiance}

There is little doubt that the INA on its face requires that applicants take an oath: "A person who has applied for naturalization shall, in order to be and before being admitted to citizenship, take ... an oath" of allegiance to the Constitution. ${ }^{107}$ The INS has read Congress's unwillingness to alter the attachment requirement for citizenship as a command to enforce the oath requirement rigorously. But it would be an error to assume that Congress will not dispense with the cerennomial oath of allegiance when other values outweigh the need for the oath. In fact, Congress has provided for at least two situations in which the oath may be altered and one in which it may be eliminated entirely. Close examination of the rationale behind the existing provision for complete exemption suggests that it should apply with equal force to severely mentally disabled imdividuals.

The first two modifications of the oath stem from Congress's desire to accommodate differences in religious opimion. The INS now recognizes that when an applicant objects to the basic concept of an "oath" as implymg belief im a Supreine Being, she may merely affirm her allegiance to the Umited States, rather than swearing it. ${ }^{108}$ In addition, despite the clear perception by Congress that military service is weighty evidence of loyalty to the United States, ${ }^{109}$ the legislature has not drawn the converse presuinption that refusal to serve necessarily implicates a lack of loyalty, but rather has made accommodations in the oath for citizenship applicants with religious objections to military service. ${ }^{110}$ These applicants are not required to pledge to support and defend the Constitution by bearing arms. ${ }^{111}$

106. See Supplemental Policy Guidance I, supra note 101, at 14-15, 74 INTERPRETER ReLEaSES at 947-48.

107. INA § 337(a), 8 U.S.C.A. § 1448(a) (West 1999).

108. See 8 C.F.R. $\$ 337.1$ (b) (1998).

109. See supra notes $79-80$ and accompanying text (discussing the reduction in required residency period and other special exemptions for veterans).

110. See INA § 337(a), 8 U.S.C.A. § 1448(a) (West 1999).

111. See id. Note that the oath's language on bearing arms has little relevance for severely mentally disabled applicants, since they are exempt from military service. See 50 U.S.C. § 454(a) 
Even in the absence of explicit instructions from Congress, the courts have occasionally been able to interpret standards for citizenship in an inclusionary fashion without losing sight of the purpose those standards serve. One line of jurisprudence that has led courts to delve into the core meaning of the oath requirement involves religiously motivated objections to pledging allegiance to any earthly authority. The trend in these cases has again been toward greater latitude in allowing applicants to naturalize. For exainple, in 1969 two Jehovah's Witnesses were denied citizenship when they explained to the court that they intended to refuse to vote, serve on juries, or otherwise participate in governmental affairs. ${ }^{112}$ Yet the following year a Jehovah's Witness with essentially identical reservations was able to take the oath and beconie a citizen. ${ }^{113}$ In approving the petition, the court noted that "it is significant that Congress has not expressly made any of the activities in question in this case prerequisites to citizenship. Involvement in politics and jury service are not the only ways to demonstrate an attachment to the principles of the Constitution ...."114 As another court put it, the phrases Congress used in crafting the statute "were not intended as rigid, inflexible rules, but rather as elastic tests to be interpreted in the light of the hopes and objectives of a free deinocratic society."115

Above and beyond its recognitions of religious freedom, Congress has explicitly outlined one situation in which the oath need not be administered at all: In cases involving naturalization of minors, if a child is incapable of understanding the nieaning of the oath, it is waived. ${ }^{116}$ Since a child inust have at least one citizen parent in order to naturalize, the waiver is intended to reflect this close familial tie to the nation. ${ }^{117}$ The waiver also prevents U.S. naturalization policy from artificially placing barriers of nationality between family menibers, ${ }^{118}$ and from excluding an otherwise eligible member of a citizen's family due solely to her inability to comprehend the

(1994) (requiring physical and mental examination to determine suitability for induction into the Armed Forces).

112. See In re Matz, 296 F. Supp. $927,929,933$ (E.D. Cal. 1969).

113. See In re Pisciattano, 308 F. Supp. 818 (D. Conn. 1970).

114. Id. at 820 .

115. In re Battle, 379 F. Supp. 334, 336 (E.D.N.Y. 1974). This is not to suggest that there are no limits to religiously based modifications of the oath requirement. In other Jehovah's Witness cases, the courts have rejected naturalization applicants who will commit to obeying only those laws that are in keeping with their spiritual beliefs. See, e.g., In re De Bellis, 493 F. Supp. 534 (E.D. Pa. 1980); In re Wilhams, 474 F. Supp. 384 (D. Ariz. 1979).

116. See INA § 337(a), 8 U.S.C.A. § 1448(a) (West 1999); 8 C.F.R. § 322.5(a) (1998). This exemption may be found as far back as the Nationality Act of 1940. See Nationality Act of 1940, Pub. L. No. 76-853, § 335, 54 Stat. 1137, 1157.

117. The House Report that accompanied the INA describes the Act as a whole as "implement[ing] the underlying intention of our immigration laws regarding the preservation of the family unit." H.R. REP. No. 82-1365 (1952), reprinted in 1952 U.S.C.C.A.N. 1653, 1680.

118. The House Report on INTCA, in discussing acquisition of citizenship by children born abroad, expresses concern that family members may "become and remain separated by nationality." H.R. REP. No. 103-387, at 5 (1994), reprinted in 1994 U.S.C.C.A.N. 3516, 3517-18. 
oath. Yet the existing waiver program leads to the absurd result that a $m i$ nor with severe mental impairment may become a citizen, while the same individual would be barred froin obtaining citizenship after her eighteenth birthday, regardless of how many other family members might have become citizens.

The vast majority of applicants with developmental disabilities seek citizenship at the same time as or after other family members. ${ }^{119}$ In addition, elderly permanent residents who lose inental capacity later in life generally have immigrated here through a child who has already acquired citizenship. ${ }^{120}$ Thus, both groups typically have the same type of close familial ties to U.S. citizens as the minors encompassed by the existing waiver. These parallel ties support the idea that congressional expansion of this exemption to include severely mentally disabled applicants, at least those with citizen guardians or conservators, would be in keeping with the waiver's present function and goals. Moreover, one might note that though these applicants emphatically should not be regarded as equivalent to children, it is a reality of existence for mdividuals with severe mental disabilities that their caregivers and family members often do inake some very fundamental decisions on their behalf. Some of these decisions, such as what country to live in, undoubtedly have as much impact on a mentally disabled person as a U.S. citizen parent's decision to seek citizenship for her minor child.

As the examples above show, despite the INS's current stance on the oath/attachment issue, neither Congress nor the courts have been entirely rigid where the oath is concerned. Strong family ties have factored into the equation, leading to a waiver of the oath for minor children of citizens who cannot understand the oath's provisions. And applicants whose religious convictions set them apart from the typical citizenship seeker have also been able to naturalize, despite needing special modifications of the oath. In these cases, policy regarding the oath has often been applied using an inclusionary model rather than an exclusionary one. The formal modification of the oath that Congress has sanctioned for religious objectors is one reflection of this ideal of inclusion. Congress there made a determination that preserving religious freedom holds a higher value than coercing proimses to demonstrate one's loyalty through military service. ${ }^{121}$

Similarly, in the 1973 Rehabilitation Act and the 1994 amendinents to the INA, Congress signaled that the mclusion and participation of disabled individuals in society are values that outweigh the need for rigid adherence

119. See Interview with Stephen Rosenbaum, supra note 17.

120. See Interview with Frank Tse, Staff Attorney, Asian Law Caucus, in San Francisco, Cal. (Feb. 19, 1999).

121. See McCarran, supra note 54, at 511. 
to restrictive and exclusionary standards. We turn now to an examination of these pieces of legislation.

\section{III}

CONGRESSTONAL EFFORTS TO ACCOMMODATE INDIVIDUALS WITH DISABILITIES ENCOUNTER INS INTRANSIGENCE

\section{A. Congress's Efforts to Accommodate Disabled Citizenship Applicants}

Congress has most powerfully evidenced its intent to accommodate disabled individuals in its landmark anti-discrimination initiative, the Rehabilitation Act of 1973. ${ }^{122}$ The Act provides access to federal employment, programs, and benefits by broadly prohibiting federal agencies from discriminating against mentally and physically disabled individuals. ${ }^{123}$ Noting that "disability is a natural part of the human experience and in no way diminishes the right of individuals" to, among other things, "enjoy self-determination," "make choices," "contribute to society," and "enjoy full inclusion and integration in the economic, political, social, cultural, and educational mainstream of American society," 124 the Act aims to enhance "respect for individual dignity, personal responsibility, selfdetermination," "privacy, rights, and equal access," and "inclusion, integration, and full participation of the individuals" with disabilities. ${ }^{125}$

Section 504, the Rehabilitation Act's core, mandates that "[n]o otherwise qualified individual with a disability in the United States ... shall, solely by reason of her or his disability, be excluded from the participation in, be denied the benefits of, or be subjected to discrimination under any program or activity ... conducted by any Executive agency." 126 This broad provision of the Act is the foundation of a substantial body of civil rights disability regulations, all of which apply to

122. Pub. L. No. $93-112,87$ Stat. 355 (1973) (codified as amended at 29 U.S.C. $\$ \S 701-796$ (1994)).

123. See 29 U.S.C. $\$ 794$.

124. Id. \$ 701(a)(3).

125. Id. \& 701(c).

126. Id. $\$ 794$. The Act defines "individual with a disability" as "any person who (i) has a physical or mental inpairment which substantially limits one or more of such person's major life activities, (ii) has a record of such an impairment, or (iii) is regarded as having such an impairment." Id. § 706(8)(B). It is important to note that, although the language of the Rehabilitation Act now reflects that of the better known Americans with Disabilities Act of 1990 (ADA), the ADA does not apply to federal agencies, including the INS. See Americans with Disabilities Act of 1990, Pub. L. No. 101-336, § 101(5)(B)(i), 104 Stat. 327, 330 (codified at 42 U.S.C. $\$ 12111(5)(B)(i)$ (1994)) (excepting federal government from definition of "employer"); $i d$. $\S 201$ (1)(A), 104 Stat. at 337 (codified at 42 U.S.C. $\S$ 12131(1)(A)) (defming "public entity" as "any State or local governinent"). The ADA does, however, borrow heavily in its terminology from the Rehabilitation Act. See, e.g., ADA § 3(2), 104 Stat. at 32930 (codified at 42 U.S.C. $\S 12102(2)$ ) (defining "disability" using the same words as $\S 7$ of the Rehabilitation Act); ADA § 501(a), 104 Stat. at 369 (codified at 42 U.S.C. § 12201(a)) (expressly preserving the standards created by the Rehabilitation Act and its accompanying regulations). 
the INS's implementation of naturalization policy. ${ }^{127}$ As the agency itself has noted: "Making acceptable accommodations or modifications to the entire naturalization process is our mandate under the Rehabilitation Act of 1973." 128

Because it operates within the confines of the Rehabilitation Act, the INS is obliged to conduct its "programs or activities," including naturalization, consistently with it. Among other things, this means that the agency must administer the oath requirement in accordance with the purpose of the Act. The Department of Justice's regulations, which stem from the Act, bar the government from utilizing "criteria or methods of administration the purpose or effect of which would... [d]efeat or substantially impair accomplishment of the objectives of a program or activity with respect to handicapped persons." 129 Nonetheless, until 1994, the capacity to take the oath was a non-issue in the context of accommodations for disabled applicants, simce the INS could simply deny applications based on an inability to comply with the English and U.S. history/civics requirements. ${ }^{130}$

However, this situation changed dramatically after the passage of the 1994 Immigration and Nationality Techmical Corrections Act (INTCA), im which Congress for the first time turned its attention to aiding citizenship applicants with mental disabilities. Recognizing the need to ameliorate the unique difficulties confronting immigrants with disabilities, Congress crafted a broad exemption from the English and U.S. history/civics requirements. Section 108 of INTCA provides that these criteria for citizenship "shall not apply to any person who is unable because of physical or developmental disability to comply therewith."131

Although this action met with broad approval from disability rights advocates and the families of disabled permanent residents, it has proved to be of limited utility for the most severely disabled applicants due to the oath issue, which never surfaced during the consideration of INTCA. ${ }^{132}$ Congress at that time had no means of foreseeing the difficulty that the oath requirement would soon pose..$^{133}$ The issue had not arisen previously

127. See 28 C.F.R. $\$ 39.102$ (1998) (noting that disability anti-discrimination provisions are applicable to all programs and activities conducted by executive agencies).

128. Supplemental Policy Guidance I, supra note 101, at 14, 74 INTERPRETER RELEASES 941, 947 (1997).

129. 28 C.F.R. $\$ 39.130(b)(3)$ (1998).

130. See Interview with Stephen Rosenbaum, supra note 17.

131. INTCA, Pub. L. No. 103-416, § 108(b)(1), 108 Stat. 4305, 4310 (1994) (codified at INA § 312(b)(1), 8 U.S.C.A. $\$ 1423(b)(1)$ (West 1999)).

132. No mention of the oath issue appears in the Congressional Record or the House Report on the bill. See H.R. 783, 103d Cong. (1993); H.R. REP. No. 103-387 (1993), reprinted in 1994 U.S.C.C.A.N. 3516.

133. The INS itself noted that prior to Congress's action, it had few applications from disabled citizenship seekers: "All these comments [on the proposed rule] liave assisted the Service in understanding matters of concern to the disabled community, a constituent group that until now the Service has only interacted with on a limited basis." 62 Fed. Reg. 12,915, 12,916 (1997). 
because anyone whose mental functioning was so impaired as to have trouble comprehending the oath would never have reached that stage of the naturalization process, but would instead have been screened out by the English and U.S. history/civics testing requirements.

Despite Congress's failure to identify and specifically address the oath issue, the 1994 Act and its legislative history clearly display an intent to facilitate, rather than impede, access to citizenship by disabled residents. The House Report accompanying the legislation notes that one of the Act's purposes was to "promote the acquisition of U.S. citizenship by relaxing or eliminating certain burdensome and unreasonable testing ... requirements." 134 Toward that end, the Act "provides a general waiver of all testing requirements for persons of any age who, because of 'physical or developmental disability or mental impairment,' could not reasonably be expected to pass the test."135 The English aud U.S. history/civics requirements are waived for those with "functioning so impaired as to render the individual unable to participate in the normal testing procedures." ${ }^{\text {136 }}$ Here, Congress explicitly recognized the impact of severe cognitive disorders on citizenship applicants, and directed the INS to make appropriate accommodations for such applicants. We turn now to the agency's response:

\section{B. The INS's Intransigent Response}

Despite Congress's 1994 directive to provide accommodations for disabled applicants, the INS continued to deny citizenship to those who could not meet the English and history/civics standards. ${ }^{137}$ It was not until November 21, 1995-more than a year after the Act passed-that the agency finally acknowledged Congress's action by issuing an internal "preliminary guidance" memorandum. ${ }^{138}$ The memorandum directed INS officers to waive the English fluency and U.S. history/civics requirements for disabled applicants, but to maintain all other requirements. ${ }^{139}$ No notice of this action appeared in the Federal Register, the usual place of publication for official changes im agency rules, ${ }^{140}$ and the details of the waiver policy were kept within the agency. ${ }^{141}$

134. H.R. REP. No. 103-387, at 3-4 (1993), reprinted in 1994 U.S.C.C.A.N. 3516, 3516.

135. Id. at 5, 1994 U.S.C.C.A.N. at 3518.

136. Id. at 5-6, 1994 U.S.C.C.A.N. at 3518.

137. See Chow v. Meissner, No. C-96-2422 SI, 1997 WL 285066, at *1 (N.D. Cal. May 22, 1997).

138. See Louis D. Crocetti, Jr., INS Associate Commissioner, Preliminary Guidance on \$ $3 I 2$ Adjudications/Mental, Physical and Developmental Disabilities (Nov. 21, 1995), reprinted in 73 INTERPRETER RELEASES 120 (1996).

139. See id.

140. See 5 U.S.C. $\$ 553$ (1994).

141. See Chow, 1997 WL 285066, at *1. 
On July 3, 1996, a coalition of attorneys in the San Francisco Bay Area filed suit to force the INS to adopt official rules implementing the 1994 amendments and to make its waiver policy public. ${ }^{142}$ Shortly thereafter the INS finally published a proposed rule, nearly two years after Congress first authorized the disability waiver for naturalization applicants. ${ }^{143}$ After the designated comment period, the agency published a final rule on March 19, 1997.144

The rule and its accompanying explanatory text provided a new Form $\mathrm{N}-648$, which allows a licensed physician to explam why, after examining an applicant, she believes that the applicant's permanent disability prevents her from learning English or U.S. history and civics. ${ }^{145}$ An official waiver of these knowledge-based requirements was thus finally available, but it was immediately apparent that a new set of difficulties lay in store for severely mentally disabled applicants. In a single paragraph, the agency noted that accommodations would only be afforded to "individuals who signal their willingness to become United States citizens and to give up citizenship in other countries." 146

In addition to the official rule, with public comments and the agency's response, the INS also circulated an internal memorandum containing further procedures for handling applications from disabled immigrants. ${ }^{147}$ This memorandum, entitled "Supplemental Field Policy Guidance," has not been officially published, despite the fact that its contents could affect the outcome of the naturalization process for many applicants. ${ }^{148}$ The memo advises INS officers that the oath requirement is to be enforced, even though it anticipates that doing so will likely disqualify severely mentally disabled citizenship applicants:

Many commenters felt that while disabled applicants are being offered an exception to the [English and U.S. history/civics requirements], this exception is undermined by requiring them to take the oath of allegiance required by section 337 of the Act. Some commenters also stated that to hold these applicants to the requirements of section 337 requires them to have some limited

142. See Low v. Meissner, No. C-96-2422 SI (N.D. Cal. filed July 3, 1996), decided sub nom. Chow v. Meissner, 1997 WL 285066.

143. See 61 Fed. Reg. 44,227 (1996).

144. See 62 Fed. Reg. 12,915 (1997). Even after the issuance of the final rule, applicants with disabilities have had to struggle to obtain waivers of the English and U.S. history/civics requirements; many report receiving abusive treatment when they attempt to apply for the waivers, and the INS has refused to grant waivers in a large percentage of cases (ninety-eight to ninety-nine percent in one informal study). See Susan Sachs, Would-Be Citizens Trip on I.N.S. Policy Hurdle, N.Y. Times, Feb. 18,1999 , at A23.

145. See 62 Fed. Reg. at 12,925-28.

146. 62 Fed. Reg. at 12,919 .

147. See Supplemental Policy Guidance I, supra note 101.

148. This is a possible violation of the Administrative Procedure Act. See 5 U.S.C. $\$ 552(a)(1)(D)$ (1994) (requiring notice of certain policy changes through pubhication in the Federal Register). 
knowledge of civics. However, Congress did not expressly waive the oath requirement .... As such, the oath is still required for all applicants.

While it is not the role of the [examining officer] to make a technical medical determination as to the existence of a disability, it is the responsibility of the [officer] at the time of the interview to be satisfied that the disabled naturalization applicant understands the nature of the actions he or she will be taking and to some extent the actual provisions of the oath. The Service believes that many disabled applicants, while excepted from the civics knowledge requirements of section 312 , will be able to have a limited but sufficient understanding of the concepts of the oath, and therefore will be eligible to complete the naturalization process. ${ }^{149}$

The INS's "accommodation" of applicants with severe mental disabilities thus amounts to the following: Examiners are directed to determine whether the applicant can understand a "simplified" version of the oath, by attempting to discern whether "the applicant understands that he or she is becoming a United States citizen, is foreswearing allegiance to his or her other country of nationality, and personally and voluntarily agrees to this change of his or her status." ${ }^{150}$ If an applicant cannot do so, he or she simply cannot be naturalized.

In response to the INS's newly articulated final rule, the plaintiffs in the California class action, Chow v. Meissner, sought to amend their complaint, focusing in part on the issue of the oath. ${ }^{151}$ Plaintiffs argued that the INS's treatment of the oath issue thwarted Congress's intent and rendered the waiver program useless to those who need it most. ${ }^{152}$ The trial court at that point dismissed the suit rather than permitting the amendment, agreeing with the INS that the agency could not infer a waiver of an existing requirement (the oath) unless specifically directed to do so by Congress. ${ }^{153}$ The court apparently sidestepped the fact that INS is already altering the oath without explicit congressional authorization by directing its officers to

149. Supplemental Policy Guidance I, supra note 101, at 14, 74 INTERPRETER RELEASES 941, 947 (1997).

150. Id. at 15, 74 INTERPRETER RELEASES at 948. The memo, however, further instructed officers not to deny applications, but to put them on hold, pending further instructions. See id. One year later, in March 1998, another internal INS memorandum instructed officers to begin issuing notices denying naturalization applications from individuals who "cannot demonstrate ... an understanding of the nature of the oath." Supplemental Policy Guidance II, supra note 17, at 1, 75 INTERPRETER RELEASES 557, 557 (1998).

151. See Chow v. Meissner, No. C-96-2422 SI, 1997 WL 285066, at *4 (N.D. Cal. May 22, 1997).

152. See id.

153. See id. 
use a "simplified" form of the oath for applicants with mental disabilities. ${ }^{154}$

In a footnote, the court found that if the plaintiffs were contending that the INS's construction of the oath requirement violates section 504 of the Rehabilitation Act, the claim was unfounded. ${ }^{155}$ The court instead held that the agency's insistence on the oath did not constitute impermissible discrimination on the basis of plaintiffs' disabilities. ${ }^{156}$ It arrived at this decision after a brief examination of the phrase "otherwise qualified individual," a term of art in disability law which has differing ineannings depending on the type of prograin imvolved. ${ }^{157}$ The court found that otherwise qualified individuals are those who "meet[] all of the prograin requirements in spite of the disability." 158 It continued by finding that the plaintiffs had "not shown... that the oath requirement is inerely a secondary requirement of the naturalization process which inay be altered or waived to satisfy reasonable accommodation standards under $\S 504$."159 Although this ruling brought an abrupt end to the suit, the court's conclusion that the INS properly applied section 504 inay have been drawn prematurely. Part IV of this Comment therefore more thoroughly explores the applicability of section 504 to the INS's administration of its naturalization prograin.

\section{IV}

Existing Disability Law, Together with the Power Delegated to THE INS IN THE IMMIGRATION AND NATIONALITY ACT, Gives the INS THE AUTHORITY to NATURALIZE APPLICANTS WITH Severe Mental Disabilities

\section{A. The Fundamental Alteration Standard of Section 504}

As the Chow case highlights, the crux of the oath debate is whether severely inentally impaired naturalization applicants are "otherwise qualified"160 mdividuals under the Rehabilitation Act. If so, section 504 of the Act requires the INS to reasonably accommodate these applicants. ${ }^{161}$ The scope of this protection depends, however, on the type of government

154. See Supplemental Policy Guidance I, supra note 101, at 15, 74 INTERPRETER RELEASES 941, 948 (1997).

155. See Chow, 1997 WL 285066 , at *4 n.13.

156. See id.

157. See id.; Rehabilitation Act $\$ 504,29$ U.S.C. \$ 794 (1994) ("No otherwise qualified individual with a disability in the United States ... shall, solely by reason of her or his disability, be excluded from the participation in, be denied the benefits of, or be subjected to discrimination under any program or activity ... conducted by any Executive ageney ....").

158. Chow, 1997 WL 285066 , at *4 n.13.

159. Id.

160. Rehabilitation Act $\$ 504,29$ U.S.C. $\$ 794$ (1994).

161. See id. 
program under consideration. ${ }^{162}$ When a program requires participants to "perform services or to achieve a level of accomplishment," a "qualified" applicant is one who (1) meets "the essential eligibility requirements," and (2) is able to "achieve the purpose of the program or activity without modifications in the program or activity that the agency can demonstrate would result in a fundamental alteration in its nature." ${ }^{163}$ By contrast, for programs which do not involve the performance of services or achieving a level of accomplishment, qualified individuals are those who meet the "essential eligibility requirements" (such as age) ${ }^{164}$ for participation or receipt of benefits. ${ }^{165}$ Which definition of "qualified individual" applies under section 504 depends on the type of program or activity in which the mdividual seeks to participate. ${ }^{166}$

Let us assume that the government's naturalization program, as operated by the INS, is one that generally requires participants to "achieve a level of accomplishment." 167 If this higher standard applies, the INS may lawfully find severely disabled applicants to be unqualified by showing that a waiver of the oath requirement would fundamentally alter the nature of acquiring citizenship. ${ }^{168}$ If applicants must indeed demonstrate "a level of accomplishment," they could most convincingly do so by satisfying the agency's standards for the two most concrete, achievement-oriented, testbased standards that citizenship applicants must meet: the English language requirement and the U.S. history/civics requirement. In its 1994 legislation, however, Congress provided for a disability-based waiver of these two components. ${ }^{169}$

If an applicant qualifies for this waiver, the remaining "standards of performance" are then five years of residence, good moral character, and attachment to the principles of the Constitution. Severely mentally disabled applicants would still need to show that they can satisfy these criteria without fundamentally altering the nature of the INS's naturalization program. Compliance with the minimum residency period and possession of good moral character (generally interpreted as a clean criminal record) ${ }^{170}$ are readily verifiable, and applicants with severe mental disabilities can satisfy these requirements in the same way as others seeking citizenship. Whether disabled or not, applicants may meet both of these standards by passively refraining from contrary activities, that is, by not committing fraud,

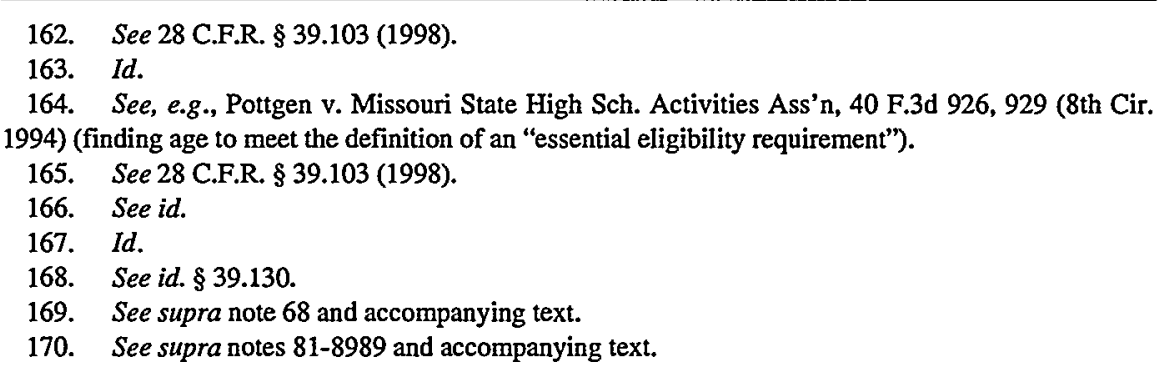


crimes, or acts of moral turpitude, and by not leaving the country for extended periods.

The final eligibility requirement, the more intangible requirement of attachment to the Constitution, is not as clearly demonstrable as its counterparts. Recall, however, that the function of the attachment requirement is "the exclusion from citizenship of applicants who are hostile to the basic form of government of the United States, or who disbelieve in the principles of the Constitution." Un1 Under this formulation of the requirement, an applicant can demonstrate attachment by refraining from action that manifests a viewpoimt contrary to the principles of the Constitution. ${ }^{172}$

As discussed in Part II.C, it is thus possible for a naturalization candidate with severe mental disabilities to demonstrate that she meets the attachment requirement, as well as the requirements of residency and good moral character. This leads us to the question of whether waiver of the oath would fundamentally alter the nature of becoming a naturalized citizen. If not, the INS, while acting in keeping with the purpose of the oath, must ensure that it does not function as an unreasonable barrier to citizenship. ${ }^{173}$

From the agency's perspective, the core issue is consent: ${ }^{174}$ Nationality is a fundamental attribute of personhood in the modern age, and one that should not be altered without the informed consent of the individual. Yet for individuals who are severely mentally impaired, family members routinely make other vital decisions regarding wliere to live, what type of medical care to receive, and, in fact, whether to immigrate to the Umited States and take up permanent residency here. ${ }^{175}$ Nowhere has the INS suggested that family members, in the absence of explicit consent, lack the right to alter their relative's status from that of non-resident alien to legal permanent resident. But as acclimation and acculturation continue with mcreasing time spent in the Umited States, and as family members begin to consider the final step of integration into the civic community through naturalization, the agency steps in, objecting to the family's exercise of their right as guardian to make decisions on behalf of their relative. The claim is that consent to the oath's provisions indicates something deeply personal: the decision to set aside previous loyalties in favor of assuming "the requirements and responsibilities of [American] citizenship."176

171. 8 C.F.R. $§ 316.11$ (a) (1998).

172. See supra Part II.C.

173. See Rehabilitation Act § 504, 29 U.S.C. $\$ 794$ (1994); 28 C.F.R. § 39.103 (1998).

174. See Supplemental Policy Guidance I, supra note 101, at 3, 74 INTERPRETER RELEASEs 941, 942 (1997) (noting that "[a]ll applicants must demonstrate some form of assent to the oath of allegiance").

175. See BAROFF, supra note 6, at 56 (describing need for close care and supervision of profoundly retarded adults).

176. Radcliffe Letter, supra note 14. 
But is this issue of the "requirements and responsibilities of citizenship" legitimate? Several cases dealing with Jehovah's Witnesses have held that a deliberate refusal to take part in civic life does not disqualify an applicant from citizenship. ${ }^{177}$ Naturalization applicants may reject military service in defense of the nation, decline to participate in the democratic process, refuse to take part in the administration of justice by serving on a jury, and decline to pledge allegiance to the flag as a symbol of this country. ${ }^{178}$ If a person can willfully reject all of these markers of membership in the American polity, yet still be admitted to citizenship, it would be truly bizarre to hold another individual at fault for an inability to take part in soine aspects of civic life.

There remains, however, the issue of loyalty to the nation. As we have seen, for Congress this is the central issue for prospective citizens. Even if one cannot or will not participate in the civic life of the country, surely at a minimum soine element of undivided loyalty to the nation must be required. In fact, though this once was the case, it is no longer so. The Supreme Court, as long ago as 1939, has recognized that dual citizenship is not fundaunentally incompatible with meeting the duties of American citizenship. ${ }^{179}$ American dual citizens may now live abroad indefinitely, ${ }^{180}$ vote in elections in their country of origin without repercussions, ${ }^{181}$ and even hold high government office abroad. ${ }^{182}$ The literal language of the oath, in which one inust "absolutely and entirely renounce and abjure all allegiance and fidelity to any foreign ... state," today serves only a ceremonial function, im many cases failing to divest the new citizen of her original nationality. Whether the clause has any effect whatsoever depends entirely on the law of the applicant's hoine country. ${ }^{183}$

Thus, it becomes apparent that in this and other respects the oath requirement constitutes not an unalterable monolithic barrier, but rather a ceremomial formality marking the successful completion of the naturalization screening process. Under the standards of section 504 of the Rehabilitation Act, waiver of the oath requirement would not result in a fundamental alteration of the "program or activity" at issue here: becoming a naturalized citizen. Unfortunately, the INS has now firmly ensconced the capacity to understand the oath as a de facto bar to citizenship when an applicant has severe mental disabilities, despite the

177. See, e.g., In re Battle, 379 F. Supp. 334 (E.D.N.Y. 1974); In re Pisciattano, 308 F. Supp. 818 (D. Conn. 1970).

178. See Battle, 379 F. Supp. at 337; Pisciattano, 308 F. Supp. at 820.

179. See Perkins v. Elg, 307 U.S. 325,329 (1939).

180. See Schneider v. Rusk, 377 U.S. 163, 166-67 (1964).

181. See Afroyim v. Rusk, 387 U.S. 253 (1967).

182. See Peter J. Spiro, Dual Nationality and the Meaning of Citizenship, 46 EmoRY L.J. 1411, 1455 n.196 (1997).

183. See Daniel Levy, Naturalization Handbook 6-9 (1998) (discussing effect of acquiring U.S. citizenship on nationals of various countries). 
availability of appropriate accommodations which would maintain the oath's function.

\section{B. Appropriate Accommodations Are Available that Are in Keeping with the Oath's Function of Screening Out Those Who Would Harm the Nation}

The oath (with its implicit component of attachment) is, as we have seen, intended at a minimum to screen out those who bear ill will toward the United States. ${ }^{184}$ To serve this essential purpose and implement Congress's desire to facilitate naturalization of disabled immigrants, the INS could make use of the other tools already at its disposal to craft appropriate accommodations. For example, the INS possesses a statutory grant of authority to accept testimony and evidence "touching or in any way affecting the admissibility of any applicant for naturalization." 185 Thus, it is within the agency's power to accept the affidavit of a family member attesting to the applicant's attachment to the principles of the Constitution and favorable disposition toward the nation. ${ }^{186} \mathrm{~A}$ parent, sibling or legal guardian, for example, could execute a sworn statement that the applicant has conducted herself in a manner consistent with constitutional principles and evincing goodwill toward the United States.

This would not be unprecedented. In the period during which federal district courts had exclusive jurisdiction over naturalization petitions, some devised their own de facto waivers of the attachment requirement. In re Rodriguez, a Texas case which dealt with an applicant's "inability to understand or explam" the principles of the Constitution, provides an especially apt example. ${ }^{187}$ There, the court rejected arguments that an applicant unfamiliar with the Constitution could not pledge to uphold its principles, and instead based its ruling on witnesses' statements that Mr. Rodriguez was an upstanding member of the community and worthy of citizenship:

That the applicant is lamentably ignorant is conceded, and that he is unable to read and write the testimony clearly discloses.

184. See supra notes $91-94$ and accompanying text.

185. INA § 335(b), 8 U.S.C.A. § 1446(b) (West 1999).

186. In the case of severely mentally disabled immigrants, strong family ties are almost always present. For those who immigrate at an advanced age and then experience a loss of mental capacity due to Alzheimer's disease or a stroke, our family-based immigration system generally ensures that they arrived via a visa petition filed by a citizen son or daughter. See Interview with Frank Tse, supra note 120. Those with congenital or childhood cognitive problems typically immigrate with their parents, since they rarely have any independent basis for obtaining permanent resident status, such as an employment-based visa. See Interview with Stephen Rosenbaum, supra note 17. When a parent naturalizes, inembers of this group acquire a close bond to a U.S. citizen. Thus a large number of incntally disabled permanent residents have close familial connections to U.S. citizens-connections which evoke the strong family ties that Congress has recognized in the context of residency requireınents.

187. 81 F. 337,355 (W.D. Tex. 1897). 
Naturally enough, his untrained mind is found deficient in the power to elucidate or define the principles of the constitution. But the testimony also discloses that he is a very good man, peaceable and industrious, of good moral character, and law abiding "to a remarkable degree." And hence it may be said of him, notwithstanding his inability to undergo an examination on questions of constitutional law, that by his daily [life, for ten years] he has practically illustrated and emphasized his attachment to the principles of the constitution. ${ }^{188}$

The applicant, having satisfied all other naturalization criteria, was then admitted to citizenship, despite his apparent lack of comprehension of several provisions of the oath. ${ }^{189}$

The Rodriguez court's procedure, in which witnesses testified to the applicant's ability to abide by the principles of the Constitution, adequately preserves the screening function of the oath. Modern-day applicants with severe mental disabilities could meet the requirement in a similar fashion by submitting sworn statements on their behalf froni family members or guardians. These witnesses' testimony could help the agency fulfill its duty of ensuring that the applicant is not "hostile to the basic form of government of the United States," and does not "disbelieve in the principles of the Constitution." 190 If the INS chose to accommodate severely mentally disabled applicants by accepting these types of affidavits on the issues of attachment and allegiance, the oath problem could be laid to rest without straining the boundaries of existing law. ${ }^{191}$

\section{CONCLUSION}

The INS's construction of the oath as a necessary component of the naturalization process rests on false premises. Where an applicant with severe mental disabilities can meet or show exemption from each of the five prerequisites for citizenship, providing an appropriate accommodation by waiving the oath does not fundamentally alter the nature of becoming a naturalized citizen. The agency is therefore required by law to provide reasonable accommodations in keeping with Congress's express goal of facilitating the participation of disabled individuals im society and its specific action to ease the burden on disabled citizenship applicants.

\section{Id.}

189. See id.

190. 8 C.F.R. \$ 316.11(a) (1998).

191. The Department of Justice, however, has rejected this proxy approach. The Department's Office of Legal Counsel has instructed the INS not to accept even legal guardians as appropriate guarantors by proxy. See Supplemental Policy Guidance I, supra note 101, at 3, 74 INTERPRETER RELEASES 941, 942 (1997). The agency's conclusion is still that "[a]ll applicants must demonstrate some form of assent to the oath of allegiance." Id. Note that this blanket statement is undermined by the long-standing existence of a waiver for minors who cannot understand the oath. See supra note 116 and accompanying text. 
The INS has nonetheless steadfastly maintained that those applicants whose mental impairments preclude them from taking a meaningful oath of allegiance are barred from citizenship, thereby placing the benefits of the 1994 disability waiver beyond their reach. Although the INS refuses to waive or modify the oath requirement, the agency does in fact have the authority to do so. Congress's disability waiver authorization, in conjunction with the reasonable accommodation requirements of the Rehabilitation Act and the existing powers delegated to the INS by the Immigration and Nationality Act, empowers the agency to waive the meaningful oath requirement if necessary. This could be done by satisfying the oath's function (excluding applicants who might endanger the security of the United States) through alternative ineans, such as having witnesses testify or submit affidavits to the effect that the applicant poses no threat to the nation.

If the INS cannot be persuaded or legally coerced to provide these types of appropriate accommodations for severely inentally disabled citizenship applicants, congressional action will be necessary to ascertain whether we as a nation intend to accord these individuals the equitable treatınent and respect that they deserve. Remedial amendinents have been proposed, ${ }^{192}$ but the current Congress is ideologically quite distant from the one which approved the disability waiver five years ago, and the viability of such proposals is uncertain. In the ineantime, we are left to puzzle over a regulation which no longer requires a knowledge of the Constitution, yet still requires applicants to understand the nature of an oath to uphold the principles of that sanie document.

192. The most direct proposal would amend the oath requirement at its source, INA section 337 See Interview with Stephen Rosenbaum, Staff Attorney, Disability Rights, Education, and Defense Fund, in Berkeley, Cal. (Mar. 25, 1998). 


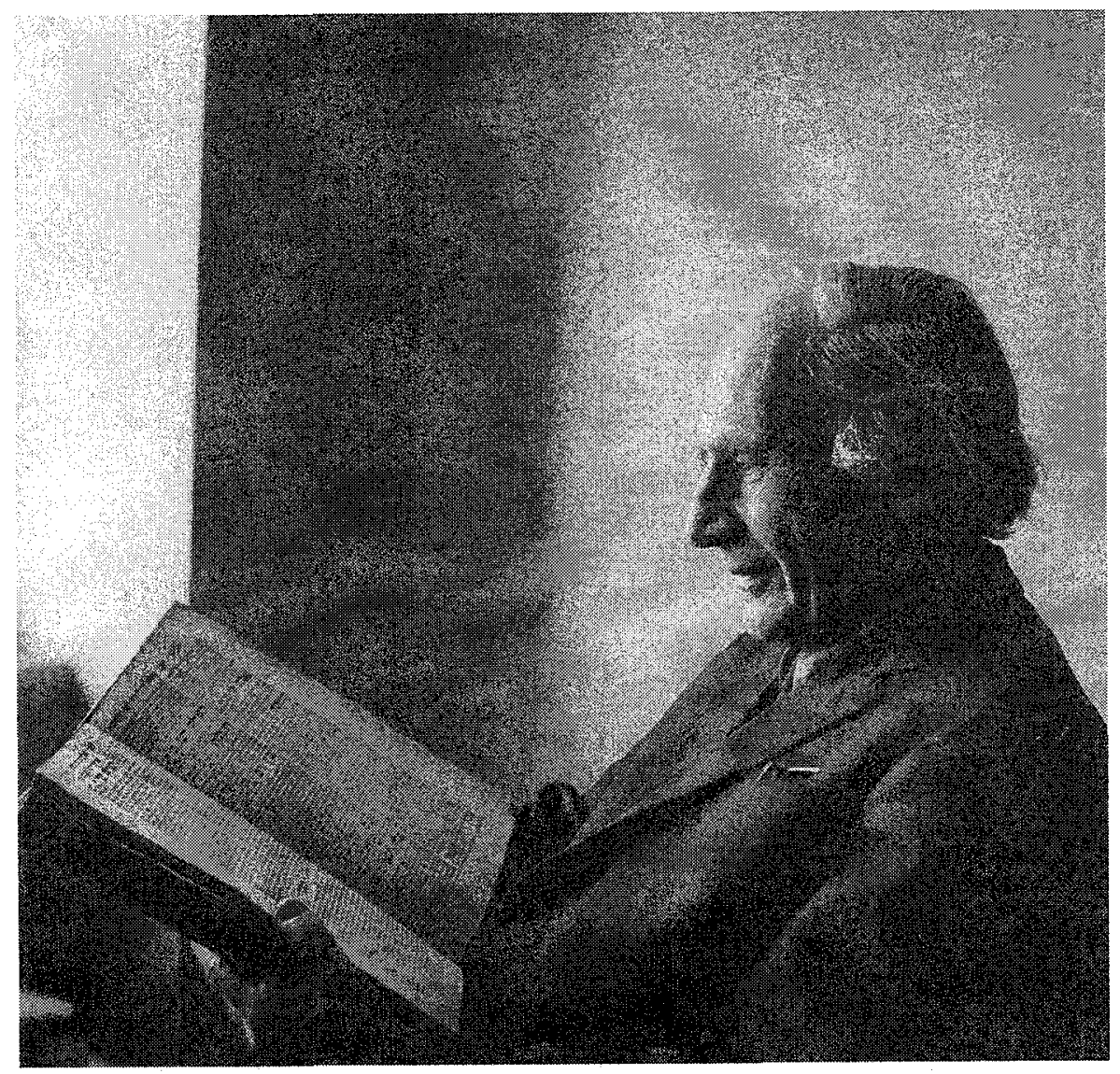

